UDC $281.5: 256 / .257(477) \ll 18 »$

DOI https://doi.org/10.32838/2663-5984/2019/4.11

Sviatnenko A.V.

National University of Life and Environmental Sciences of Ukraine

\title{
CHARITY AND CULTURAL-EDUCATIONAL ACTIVITIES OF THE ORTHODOX CHURCH IN THE RIGHT-BANK UKRAINE AT THE END OF THE XVIII - FIRST HALF OF THE XIX CENTURY: HISTORIOGRAPHY
}

The article analyzes and systematizes the historiographical work on the activity of the Orthodox Church in Right-Bank Ukraine, describes the achievements and defines gaps in the research on the subject, outlines the views of contemporary national scholars and their justification for the contribution of the church and spirituality, the contribution of the church and spirituality on Right-Bank Ukraine, as well as the content and perspectives of the research on the announced topic are outlined. The subject of intelligence that is grounded views of contemporary national researchers toward the place and role of the Orthodox Church in the social and cultural life of the country during the end of the XVIII - first half of the XIX century is emphasized. The attention is drawn to the fact that the interest in church history, its activity is conditioned by the long-awaited opportunity to carry out the ideologically not engaged, free from established stereotypes and biased attitude to religious subjects of research.

At the same time, it is emphasized that there is still no precise comprehensive study of the cultural, educational, and philanthropic activity of the Orthodox Church in Right-Bank Ukraine at the end of XVIII - the first half of the XIX century. Researchers are limited to the coverage of a particular activity of the church; the geographical boundaries of facts are not beyond the eparchial-provincial. The timeline of events mainly refers to the second half of the XIX century. The problems of functioning of church libraries, the chronicle activity of monasteries, and ecclesiastical figures, the state of church museums remain without the attention of scholars. Therefore, in contemporary national historiography, the issue of the educational activities of the Orthodox clergy on the Right Bank in the outlined period is covered. However, the absence of works that would comprehensively cover the entire spectrum of cultural and educational activities make it impossible to determine the place and role of the clergy in the development of education in the region. A particular gap in contemporary historical science is the lack of attention to the study of the basic directions, forms, and scope of the charitable activity of the church in Right-Bank Ukraine.

Key words: historiography, cultural, educational, charitable activity, Orthodox Church.

Formulation of the research problem. Today, there is an increased interest in the historical past of the church, religious traditions of the Ukrainian people, socio-cultural spheres of the clergy. The mentioned claim is connected to the fact that the "church" theme was not included in the priority for a long time, was concealed, and was often banned. Therefore, the diverse activity of the church, its participation in the social and cultural life of Ukraine has not been objectively covered in scientific research. However, without reconstruction of the diversity of activities of the Orthodox Church, it is impossible to recreate an accurate picture of the history of the Ukrainian people. Depoliticization of research, access to once-closed archival funds, and the possibility of impartial analysis of events have prompted many scholars to choose religious subjects as their subject of exploration.

An essential role in the socio-cultural life of RightBank Ukraine during the outlined period undoubtedly belonged to the Orthodox denomination. Its interests, opportunities, the scale of activity, and level of influence on the population at that time can hardly be exaggerated. It is the church organizations, the clergy, who, through their activities, formed the public opinion, attitude to political, religious, and cultural processes in the country. Without analyzing the consequences of the Orthodox Church's actions, Ukraine's history would seem incomplete.

Recently, there has been a tendency to increase the influence of church structures on the development of socio-political and socio-cultural processes in the country. The restoration of the place and role of the Orthodox Church in the history of Ukrainian society will allow us not only to appreciate the events of the past but to understand the present better.

Set of the research objectives. The purpose of scientific researchis to: analyze and systematize the historiographical work connected with the study of 
various aspects of the activity of the Orthodox Church on Right-Bank Ukraine by national scientists, to characterize the achievements and to determine the gaps of the subject, to find out new views and attitudes of the scholars in the study, culture, philanthropy in Ukraine, outline the content and perspectives of scientific research on the described issues.

The objectof the study is the state and development of contemporary national historical thought in the process of studying the cultural, educational, and charitable activities of the Orthodox Church in RightBank Ukraine during the late XVIII - early XIX centuries.

The subjectof the study is the scientific opinion of modern national researchers toward the place and role of Christian churches in the social and cultural life of the country during the end of XVIII - the first half of the XIX century.

The choice of the chronological boundaries of the study (the 90s of the XX - the beginning of the XXI century) is conditioned by the beginning of ideologically not engaged, free from established stereotypes of scientific researches on the history of the church in Ukraine, which are based on the objective analysis of a wide array of archival and scientific sources.

The primary research material outline. History of the church in Ukraine at the end of XVIII - the first half of the XIX century has numerous historical research that emerged during the late XX - early XXI centuries. However, there is no comprehensive scientific work on the cultural, educational, and charitable activities of the Orthodox Church on the territory of Right-Bank Ukraine in the indicated period till current times. There is also no general historiographical study of the problem.

A wide range of issues concerning the study of church history is outlined by researchers at scientific regional, nationwide, and international conferences, "round tables", which have been held regularly in Ukraine since 1992 [1]. Interesting and thorough intelligence on the issue was published on the pages of the magazines "УІЖ", "Kyivska Starovyna", "Archivy Ukrainy", etc.

An essential contribution to the coverage of the problem was the work of O.P. Krizhanovsky, S.M. Plochiy "History of the Church and Religious Thought in Ukraine", in which researchers provide a panorama of church and religious life in Ukraine, highlight the structural organization of the Orthodox Church, consider both socio-economic and cultural-educational areas of activity.

A separate section of the paper is devoted to the characteristics of church charity, the analysis of the spiritual education system, and monastic public schools. The contribution of the church to the overall development of the country's culture is briefly outlined. However, the full chronological (XVIII - first half of XIX century) and geographical (whole territory of Ukraine) borders of the study did not allow the authors to disclose the activity of the churches on Right-Bank Ukraine fully. Emphasis was shifted to Left Bank and Sloboda Ukraine, with a particular focus on the Greek Catholic Church and numerous monastic orders [2].

The work of V.I. Ulyanovsky is widely used [3] and provides information on the activities of Orthodox dioceses, reveals the state-legal status of the church and the peculiarities of internal church self-government.

Significant refinement of Ukrainian historiography regarding the retrospective view of the historical development of the Orthodox denomination was the publication of the 10-volume study "History of Religions in Ukraine" [4]. The third volume on the activities of the Orthodox Church in Ukraine is of particular interest. Along with an in-depth analysis of the evolution of the church, the relationship between the Orthodox and Greek Catholic churches is examined, and it is concluded that due to the persistent efforts of the Russian synodal authorities, relations between these denominations have continuously become conflicting. The relationship between churches, on the one hand, and culture, education, on the other, is widely studied.

A separate section of work is devoted to the development of such a religious institute of the church as monasteries. It is noted that their integration into state Orthodoxy led to their loss of active and independent national-cultural position in the XIX century. However, the cultural and educational activities of the clergy of the Orthodox denomination are briefly covered.

The analysis of the religious situation, the processes of autocratic unification of churches on the Right Bank, administrative-church reforms, secularization measures, problems of organization and functioning of the system of management in dioceses is devoted to several scientific works of modern researchers [5]. These works are general, but they can serve to understand and evaluate the historical background against which the activity of the religious Orthodox clergy unfolded.

Some aspects of the Orthodox Church's activity have become the subject of the unique analysis by national researchers. The research of O.A. Chirkova is devoted to the topic of the history of spiritual edu- 
cation [6]. In particular, the author gives an accurate description of the activities of the diocesan bishops, to improve the position of the clergy, and analyzes the course of reforming the educational institutions. In the research of G.V. Stepanenko, the holistic picture of the educational activity of the Orthodox clergy has been comprehensively analyzed and created, its social significance has been shown, and the educational activities of scholars of theological seminary have been investigated [7].

However, the materials on which the works were based did not allow the authors to cover the activities of the clergy in the Podilskyi province, which is part of Right-Bank Ukraine. Besides, a sufficiently broad chronological framework of the research prevented the authors from concentrating on the achievements of the clergy in the field of education in the first half of the XIX century.

The work of V.V. Babichuk is devoted to the analysis of the role of the Orthodox Church in the implementation of the educational policy of the autocracy in Volyn [8]. The author proved that the Russian government used the Orthodox Church in its intention to increase its influence among the local population by placing it under the obligation to open and maintain parish schools, to provide them with teaching staff. The tendencies found in the educational sphere revealed by the researcher are reduced to an increase in the number of Russian educational institutions, on the one hand, and on the other, the distrust of the local population in schools opened by the authorities and the Orthodox Church.

The Doctor of History of the Ukrainian Orthodox Church, V.Ye. Rozhko dedicated the own research to the development of spiritual education in Volyn. Thus, the further studies are the ones that should be mentioned: "Spiritual Orthodox educational institutions in Volyn region of the X-XX centuries: historical and local history essay" (Lutsk, 2002), where the process of assembling a network of spiritual schools is outlined in chronological order; "Volyn Theological Seminary (1796-2004): a historical essay" (Lutsk, 2004), which provides a comprehensive report of the history of this spiritual educational institution, presents the causes and consequences of the foundation, activity of all four, depending on location, periods of existence, external and internal condition of the seminary. Attention is drawn to the educational level of academics, the quantitative and social composition of students; the curriculum is analyzed. A separate section is dedicated to prominent figures of the Volyn Theological Academy. The author directed his scientific interest to the study of the history of Orthodox monasteries, proving that they were cultural and educational centers of Volyn [9].

O.B. Kachkovsky, A.G. Filinyuk analyzed the complexity and contradiction of cultural and educational life in Podillya [10]. Certainly, A.G. Filinyuk underlined the following circumstances that adversely affected the activities of the Orthodox clergy: ignoring and restraining the czarist regime development of cultural values of Ukrainians, giving preference in the Ukrainian territory to all Polish and then Russian; the existence in the region of a limited circle of Ukrainian elite focused on attracting peasants to the peaks of national education and culture; the absence of measures of autocracy aimed at protecting the Orthodox Church from the dominance of Catholicism. At the same time, the author reveals positive trends. In his view, the drive to protect the own national and cultural values was gaining ground among Orthodox priests against the backdrop of the decline of traditional forms of spiritual life. National education in the province was not so much in the preservation and development of Ukrainian schools, but in the mobilization of forces to fight against Russian and Polish influence, in closer unity of the Orthodox clergy. The researcher believes that the consequence was the beginning of the national and cultural revival. This data is based on a broad source base. Particular attention was paid to the activity of the Podilskyi Seminary, its financial position, pedagogical composition, provision of educational literature. However, the framework of scientific work did not allow us to elaborate further on the functioning of other educational establishments in the region.

N.A. Shyp devoted a number of her works to various aspects of the educational activity of the Kyiv Theological Academy [11]. The author did not proceed from what this educational institution did not do, but what benefit it gave in the unfavorable conditions of the imperial policy on Ukrainians by analyzing the publishing business, the participation of the Academy and its mentors in the creation of scientific societies, organizations and scientific events.

Various aspects of the charitable activity of the Orthodox Church were reflected in the dissertations by O.V. Kravchenko, and S.I. Poliarush [12]. They attempt to reveal the role of the church in the country's public life. However, the system of charitable activities of the clergy of Right-Bank Ukraine remained beyond their attention.

Modern domestic scholars have paid some attention to the study of this kind of educational activity of the church as book printing. It is worth mentioning Y. Isaevich's monograph "Ukrainian Book 
Publishing: Origins, Development, Problems" [13]. An attempt was made to outline the main trends in the development of printing in a separate section on the state of the problem in the XIX-XX centuries to determine the place in this process of national book publishing. Although the author focuses on the functioning of state-owned, private printing companies. The influential monastery printing houses of the Kyiv-Pechersk Lavra are considered briefly, its activity is outlined schematically and touches the period until the end of the XVIII century.

V.E. Rozhko did research concerning the process of origin and development of Orthodox book printing in Volyn. Thus, in the work "Ukrainian Orthodox Bibliography and Book Printing in Volyn (IX-XX centuries): a historical and local history essay" [14] revived the memory of small monastery printing houses in the historical Volyn based on extensive documentary and historical sources. The author paid particular attention to the study of the activity of the Basilian printing work in the Pochaiv Monastery. $\mathrm{He}$ proved that during this period, the quantity and quality of book publishing increased. He emphasized that the liturgical and theological printed works differed in the Ukrainian Orthodox direction and were mostly published in the Ukrainian language. He stressed that at the time of the subordination of the Pochaiv Lavra to the Orthodox Church, which at that time was already utterly dependent on autocracy, the monastery printing house did not lose its importance as a center for book printing.

This area of activity of monasteries is also represented in the article by V.V. Klimov, "Monastic book printing in the context of the history of the Orthodox Church in Ukraine" [15]. By analyzing the decrees, circulars, instructions of the tsarist authorities on church book printing in Ukraine, the researcher concludes that their purpose was to carry out a large-scale process of cultural and ecclesiastical unification.

Noteworthy are the works aimed at covering the history of monasteries and churches on the Right Bank, which examined the traditions of chronicles, library affairs [16], temple building [17], charitable events [18].

The scientific conference "The role of libraries of monasteries, cathedrals and other cultural institutions of Ukraine" is dedicated to the tradition of chronicle chronicles to highlight the role of libraries of monas- teries, cathedrals that have operated in Ukraine over its centuries-old history. The impressive report is presented by I.G. Pashchuk, G.A. Zagorodnya, P.V. Holobutsky, E.M. Zhludko, M.A. Shamray, etc. [19]. There are specific steps in studying the peculiarities of functioning, conditions of storage, rules of using library funds on the example of individual monasteries and cathedrals teaching in the work of T. Gorbatenko [19].

Conclusions. The previously presented material presents a case that, at the present stage in Ukraine, much attention is paid to the multifaceted coverage of the problems of the historical development of the Orthodox Church. However, despite the considerable number of publications on this subject, there is still no comprehensive study of the cultural, educational, and philanthropic activities of the Orthodox Church in Right-Bank Ukraine at the end of XVIII - the first half of the XIX century. Most of the works of contemporary national scholars treating the history of the denomination by covering only one of the outlined activities. The geographical scope of the research is generally not beyond the eparchial boundaries. The vast majority of researchers focus on the activities of the church since the second half of the XIX century, and the outlined period remains poorly researched. Only certain aspects of this issue are studied, and mainly in the context of the research of political, socio-economic conditions of the church.

Nowadays, the functioning of church libraries, the chronicle activity of monasteries, and ecclesiastical figures, and the state of church museums remain without the attention of scholars. More widely, in contemporary national historiography, the issue of the educational activities of the Orthodox clergy on the Right Bank in the outlined period is covered. However, the absence of works that would comprehensively cover the entire range of cultural and educational activities does not make it possible to determine the place and role of the clergy in the development of education in the region. A particular gap in modern historical science is the lack of attention to the study of the basic directions, forms, and scope of the charitable activity of the church in Right-Bank Ukraine.

Thus, it can be argued that the cultural, educational, and charitable activities of the Orthodox Church in Right-Bank Ukraine in the chronologically defined period are relevant and promising for future scientific researches.

\section{References:}

1. Історія релігій в Україні. Тези повідомлень II круглого столу. Львів, 1992. 83 с.; Релігія і церква в національному відродженні України. Тези наукової конференції. Тернопіль, 1993. 93 с.; Роль бібліотек монастирів, соборів та інших установ культури України. Тези наук. конф. Київ, 1993. 130 с.; Православ’я - 
наука - суспільство: проблема взаємодії. Матер. Всеукр. науково-практ. конференції. Черкаси, 2003. 66 с.; Православні духовні цінності і сучасність. Матеріали Міжнар. наук.-практ. конф. Київ, 2004. 139 с.; XVII Міжнародна наукова конференція «Історія релігії в Україні». 16-17 травня 2017 р. Київ. 197 с.; VIII Міжнародна наукова конференція «Православя в Україні». 23 листопада 2018 р.; XXIX Міжнародна наукова конференція «Історія релігій в Україні». 21-23 травня 2019 р. Львів.

2. Крижанівський О.П., Плохій С.М. Історія церкви та релігійної думки в Україні. Київ, 1994. 336 с.

3. Ульяновський В.І. Історія церкви та релігійної думки в Україні. Київ, 1994. 256 с.

4. Історія релігії в Україні : у 10 т. / під ред. А. Колодний. Київ, 1996-2003.

5. Українська церква між Сходом і Заходом / під ред. П. Яроцького. Київ, 1996; Спінул О.В., Чиркова О.А. Органи єпархіального управління Київської митрополії у XVIII-XIX століттях. Київ, 1997; Із історії православної церкви в Україні : збірник наукових праць. Київ, 1997; Слободянюк П.Я. Українська церква: історія руїни і відродження. Хмельницький, 2000; Адміністративно-територіальний устрій Поділля: Історія і сучасність : монографія / за заг. ред. Смолія В.А., Слободянюка П.Я. Хмельницький, 2005. 400 с.

6. Чиркова О.А. Православна церква в Україні в кінці XVIII-XIX ст. (на матеріалах «Київських Спархіальних відомостях», «Полтавських Єпархіальних відомостях», «Чернігівських Єпархіальних відомостях») : дис. ... канд.. іст. наук. Київ, 1998.

7. Степаненко Г.В. Освітня діяльність православного духовенства в Україні (XIX - початок XX ст.) : дис. ... канд. іст. наук. Київ, 2002.

8. Бабійчук В.В. Російська Православна церква в освітній політиці самодержавства на Волині в кінці XVIII-XIX столітті. Історія міст і сіл Великої Волині : науковий збірник «Велика Волинь». Житомир, 2012. Т. 25.

9. Рожко В.С. Православні монастирі Полісся. Луцьк, 1996; Православні монастирі Волині. Луцьк, 1997; Древні святині Полісся. Луцьк, 2008. 152 с.; Православні святині історичної Волині. Луцьк, 2009. 560 с.

10. Качковський О.Б. Освіта на Поділлі в XIX ст. Освіта, наука і культура на Поділлі. Кам'янецьПодільський, 1998; Філінюк А.Г. Освіта на Поділлі на рубежі XVIII-XIX ст. Хмельницький, 2009.

11. Шип Н.А. Видавнича і просвітницька діяльність Київської духовної академії. Київська старовина. 1999. № 3. С. 3-16; Київська духовна академія - центр вищої духовної освіти Наддніпрянської України (XIX - початок XX ст.) УІЖ. 1999. № 2. С. 63-71; Інтелектуальний потенціал Київської духовної академії (1819-1869 рр.). Православні духовні иінності і сучасність : Матеріали міжнародної науково-практичної конференції. Київ, 2014. С. 32-41.

12. Кравченко О.В. Благодійна діяльність православної церкви в Харківській єпархії (1799-1917рр.) : дис. ... канд. іст. наук. Харків, 2003; Поляруш С.І. Становлення і діяльність органів державної опіки та громадської благодійності на Лівобережній Україні (1775-1918) : дис. ... канд. іст. наук. Київ, 1996.

13. Ісаєвич Я. Українське книгодрукування: витоки, розвиток, проблеми. Львів, 2002. 520 с.

14. Рожко В.С. Українське православне книгописання і книгодрукування на Волині (XI-XX ст.) : (історико-краєзнавчий нарис). Луцьк., 2005. 256 с.

15. Климов В.В. Монастирське книгодрукування в контексті історії Православної церкви в Україні. Бібліотечний вісник. 1993. № 5/6. С. 55-61.

16. Ломачинська І. Просвітницька діяльність Київських монастирів. Київська старовина. 1997. № 6. С. 132-141; Степовик Д. Історія Києво-Печерської лаври. Київ. 2001. 552 с.

17. Годованок С.М. Монастирі та храми Волинського краю. Київ, 2014. 176 с.; Горбик О.О. Римо-католицькі костьоли Києва і Київщини. Київ, 2014. 128 с.

18. Градовський П.М. Історія Забрідської церкви на Житомирщині. Житомир, 2002. 36 с.

19. Роль бібліотек монастирів, соборів та інших установ у розвитку культури України. Тези наукової конференції. Київ, 1993. 130 с.

20. Горбатенко Вплив монастирських бібліотек на формування писемної культури Русі-України. Християнство в Украӥні на межі третього тисячоліття. Івано-Франківськ, 2002. С. 13-16.

\section{СвЯТНеНКО А.В. ДОБРОЧИННА ТА КУЛЬТУРНО-ПРОСВІТНЯ ДІЯЛЬНІСТЬ ПРАВОСЛАВНОЇ ЦЕРКВИ НА ПРАВОБЕРЕЖНІЙ УКРАЇНІ НАПРИКІНЦІ ХVІІІ - У ПЕРШІЙ ПОЛОВИНІ XIX СТ.: ІСТОРІОГРАФІЯ ПРОБЛЕМИ}

У статті проаналізовано і систематизовано історіографічний доробок щодо діяльності православної церкви на Правобережній Україні, охарактеризовано здобутки та визначено прогалини в дослідженнях із окресленої тематики, з'ясовано погляди сучасних вітчизняних науковиів і їх обтрунтування щодо внеску церков і духівництва в розвиток культури, просвіти, доброчинності на Правобережній Україні, окреслено зміст і перспективи наукових досліджень із оголошеної тематики. Підкреслено, що предметом розвідки є погляди сучасних вітчизняних дослідників на місце і роль православної иеркви в суспільному та культурному житті країни в період кінця XVIII - першої половини XIX ст. 
Акиентовано увагу на тому, що інтерес до иерковної історії, ї̈ діяльності зумовлений довгоочікуваною можливістю проведення ідеологічно не заангажованих, вільних від усталених стереотипів і упередженого ставлення до релігійної тематики досліджень.

Наголошується, що й досі у вітчизняній історіографії немає иілісного трунтовного дослідження культурно-просвітницької та благодійнииької діяльності православної иерков на Правобережній Україні кіния XVIII - першої половини XIX cm. Дослідники обмежуються висвітленням окремого виду діяльності иеркви, географічні межі розвідок не виходять за рамки єпархіально-губернських. Хронологія подій переважно стосується другої половини XIX cm. Поза увагою науковців залишаються проблеми функиіонування иерковних бібліотек, літописна діяльність монастирів і иерковних діячів, стан иерковного музейництва. Ширше в сучасній вітчизняній історіографії висвітлено питання просвітницької діяльності православного духівництвва на Правобережжі в окреслений період. Проте відсутність праць, які б комплексно висвітили весь спектр культурно-просвітницької діяльності, не дозволяє визначити місие і роль духовенства в розвитку освіти в регіоні. Певною прогалиною сучасної історичної науки є недостатня увага до вивчення основних напрямів, форм і масштабів доброчинної діяльності иеркви на Правобережній Україні.

Ключові слова: історіографія, культурна, просвітня, доброчинна діяльність, православна иерква, Правобережна Україна. 